Metropolitan Railway was issued, the object being to encircle the metropolis with a tunnel. The scheme, of which Mr. Charles Pearson, a city solicitor, was the author, was at first received with derision, and it was not until 1863 that the first section of the line, from Farringdon Street to Bishop's Road, was opened. The seven stations which formed this line have now increased to 226, and considerably more than a million passengers per day are carried. Every weekday, 2,800 trains pass through Charing Cross station. After forty years of steam, the Metropolitan and the District Railways were equipped for operation by electricity. The great extension of London's underground railways and the equipment for electrical operation of the older steam lines was started in 1902 by the formation of the Undergound Electric Railways Co. of London, Ltd., the site for the generating station being in Lots Road, Chelsea. The great success of the undertaking is due to the recognition by the administration of the fact that the position is continually changing and that progress cannot be checked or thwarted in a living organisation.

The Lots Road Station is situated on the bank of the Thames at Chelsea and is well known to Londoners. The amount of power generated per square foot of engine room area is six kilowatts, which is the highest figure for Great Britain. The Neasden power station near Wembley Park supplies nearly 100,000 kilowatts, which is a third of that supplied by Lots Road. The original plant was designed to operate with a steam pressure of $180 \mathrm{lb}$. per sq. in. and a temperature of $550^{\circ} \mathrm{F}$.; the present plant operates at a pressure of $265 \mathrm{lb}$. per sq. in. and $750^{\circ} \mathrm{F}$. To supply the condensers with the necessary water, four artesian wells were sunk to depths varying between $400 \mathrm{ft}$. and $600 \mathrm{ft}$. and these yield about 18,000 gallons her hour. After passing through the condensers, the water is cooled in wooden towers and utilised over again. The electric transmission of energy is on the three-phase system at 11,000 volts, and many hundreds of miles of three-core cable at this pressure are used. The distribution voltage on the track is 630 direct current, the alternating current being converted to direct current either by rotary converters or mercury arc rectifiers. The first escalator was installed at Earl's Court Station in 1911, and wherever escalators have been installed there has been a notable increase in the traffic. In the event of any interruption to the train service, precautions are taken that there will be no delay in the issue of instructions to all sections concerned. At such points a loud speaker is installed and emergency messages are received from a central microphone in the control room at Leicester Square station.

\section{International Congress of Anthropology and Ethnology}

Arrangements are now well advanced for the first session of the International Congress of Anthropological and Ethnological Sciences, which will be held under royal patronage in London on July 30 August 4 next. The proposal to hold a congress of this nature was first made in 1912, when the International Congress of Americanists met in London, but the meeting in 1916, for which arrangements were then made, had to be postponed indefinitely owing to the War. In future the Congress will be held every fourth year, alternating with the International Congress of Archæological and Proto-historic Sciences, which will be held in the second of the intervening years. The Anthropological Congress will coincide with the meeting in Europe of the International Congress of Americanists, which this year is to be held at Seville. The sessions of the Congress will be held at University College, Gower Street, and at the Wellcome Historical Medical Museum. The president is Lord Onslow and the chairman of the executive committee, Capt. T. A. Joyce. Prof. J. L. Myres and Mr. A. H. Brodrick are the joint honorary secretaries and Mr. H. G. Beasley the treasurer. Presidents of sections are Prof. G. Elliot Smith (Anatomy and Physical Anthropology), Mr. F. C. Bartlett (Psychology), Prof. C. B. Fawcett (Demography), Dr. A. C. Haddon (Ethnography), the Rev. E. Smith, president of the Royal Anthropological Institute (Subsection of African Ethnography), Mr. H. Balfour (Technology), Prof. C. G. Seligman (Sociology), Prof. E. O. James (Religions) and Dr. Alan H. Gardiner (Languages and Writing). Among the vice-presidents are the Archbishop of Canterbury, the Lord Mayor of London, the High Commissioners of India and South Africa, Sir James Frazer, and the presidents of the Societies of Antiquaries, the Folklore Society and the Royal Asiatic Society. Particulars of the Congress may be obtained from the Royal Anthropological Institute, 52 Upper Bedford Place, W.C.1.

\section{Archrology and Unemployment in the United States}

IN the United States advantage is being taken of the funds available for the relief of unemployment to carry out certain archæological investigations which hitherto, although considered of great importance, have been regarded as too costly for the resources of the Smithsonian Institution, Washington. The funds are to be provided by the Civil Works Administration and about one thousand men of the local unemployed will be engaged for the work of excavation. According to an announcement issued by the Smithsonian Institution, six Indian mound sites, each considered to be key positions in an archæologically unknown area, are to be explored. In each case the work will be carried out under the direction of an official of the Bureau of American Ethnology. Three sites in Florida will be in charge of Mr. Matthew W. Stirling, chief of the Bureau, one of these being an extensive system of preSeminole mounds and earthworks near Lake Okechobee which was discovered in 1931 ; Dr. F. H. H. Roberts, Jr., will excavate a group of mounds in the Shiloh National Military Park at Pittsburg Landing, Tennessee; and Dr. W. F. Strong will be in charge of the exploration of a large mound six miles from Taft, Kern County, California, one of the key sites of Californian prehistory, which is known to have been abandoned soon after the first Spaniards reached the country. At Macon, Georgia, a mound thought to be the site of an ancient Hitchi village 
will be explored. While deploring the circumstances which have made these undertakings possible, archæologists welcome the expenditure of funds in this direction, which, it is hoped, will at least make a beginning in putting the archæological exploration of the south-eastern States on the same systematic basis as the exploration of the south-west.

\section{Coventry Libraries}

THE Coventry Libraries and Museum Committee's report on the work of the year 1932-33 gives evidence of vigorous growth of the services under its care. The Committee fosters the closest possible contact between the libraries and all activities of a cultural character, and is providing additional accommodation for such activities adjacent to its central library, where already during the past year meetings of societies devoted to the study of art, history, natural history, the drama, engineering, bee-keeping, etc., numbered 271, including 120 meetings of groups for the discussion of broadcast talks. Among the most popular of the subjects of these discussions was "Biology and Everyday Life". Provision of books for children through the school library system, serving 55 schools and supplementing the activities of the special junior departments of the libraries, accounts for one sixth of the total issues. Through the West Midlands Regional Library Bureau, the resources of many libraries in other parts of the country were drawn upon by way of temporary loans to meet special requisitions. By the circulation of publicity material among branch libraries, the maintenance of a variety of book displays throughout the system was ensured. Some of the most popular displays related to cooking, wireless, gardening, polar exploration, holiday literature, modern drama and home decoration. Among other services successfully maintained are: the Coventry Bookshelf, a monthly medium of communication with readers ; an "Illustrations Collection" of 15,000 pieces ; a "lucigraph" for making facsimile copies of maps, prints, drawings, etc.; a commercial and technical intelligence service, equipped with up-to-date indexes to practically all technical material published throughout the world, patent abridgments, consular and diplomatic reports, etc.; and frequent exhibitions of matorial relating to matters of special local or regional importance.

\section{Reform of Medical Education}

IN his Bradshaw lecture recently delivered before the Royal College of Physicians, Dr. C. S. Myers discusses the education of the medical student from the point of view of the industrial psychologist. As regards pre-medical study, which consists of physics, chemistry and biology, he considers that far more time is spent in practical work on such subjects than is necessary for those who are not going to specialise in any of them, especially as they have no educational value for the future doctor. A similar criticism is directed against the enormous amount of detail in anatomy and physiology required of the student, whereas little attempt is made at this stage to gather anatomical information from the corpse in the postmortem room. The student derives his knowledge of human anatomy mainly from dissection of the cadaver, in which the desiccated organs have lost their form and their relations in the living body. As a remedy for these and other defects in medical education, Dr. Myers makes the following suggestions. In the first place, the student should spend part of his time in the wards as soon as he begins to study anatomy and physiology. Secondly, during the hospital period, he should receive a more complete education in the whole range of medicine and surgery before he attends the specialist departments. Thirdly, some training in the recognition and treatment of psychoneuroses is necessary for the future general practitioner, who is too liable to mistake the true nature of such conditions. Lastly, before entering into general practice, he should serve an apprenticeship between the passing of the qualifying examination and the actual conferment of the diploma or degree.

\section{Australian Meteorological Data}

THE Council for Scientific and Industrial Research of the Commonwealth of Australia has published valuable meteorological statistics under the title "Meteorological Data for Certain Australian Localities" (Pamphlet No. 42, Melbourne, 1933). A. foreword explains that, for some time past, various investigators on the Council's staff had made extensive use of unpublished data collected by the Commonwealth Meteorological Bureau, in connexion with researches in soil science, entomology, plant industry, animal health, etc., and it was thought worth while to make such information more accessible to investigators by publishing selected data. The matter was discussed with the Meteorological Bureau, and it was agreed that the Bureau should provide the data and arrange the material in a form suitable for publication, while the Council would bear the costs of publication. This pamphlet is the result of the co-operation of those two bodies. It gives in tabular form, for several hundred stations in Australia and Tasmania, mean monthly and annual values of daily maximum and minimum temperature and relative humidity, and average monthly and annual totals of rainfall. These averages refer to periods of varying length, as a rule not less than 15 years, and in not a few cases between 70 and 80 years. In the rare cases where the period is only five or six years, the figures may-especially in the case of such a variable quantity as rainfall-depart considerably from those that would be found over a suitably long period, but this drawback is nearly always met with in meteorological statistics for sparsely populated countries, and recourse must be had to such short records if large areas are not to be left unrepresented. A large folding map is attached at the end of the publication, which gives the meteorological divisions adopted by the Bureau and shows many of the stations included in the tables.

\section{Eugenics in Vera Cruz}

IN December 1932 a new eugenic law was enacted in the State of Vera Cruz, which has the largest population in Mexico. A Bureau of Eugenics and Mental Hygiene was organised as a part of the 